\title{
Seroprevalence of Newcastle Disease Virus in Backyard Chickens at Gazipur District of Bangladesh
}

\author{
Hossain $\mathrm{MB}^{1}$, Islam $\mathrm{MZ}^{2}$, Bari $\mathrm{MS}^{3}$, Torab $\mathrm{MA}^{4}$ and Mondal $\mathrm{MAH}^{5}$ \\ ${ }^{1}$ Department of Physiology, Biochemistry and Pharmacology, ${ }^{2}$ Department of Microbiology, ${ }^{3}$ Department of \\ Dairy and Poultry Science, ${ }^{4}$ DVM Student, Chittagong Veterinary and Animal Sciences University, Khulshi, \\ Chittagong-4202, Bangladesh, ${ }^{5}$ Doctor's Poultry and Dairy Laboratory, Mawna Chourasta, Sreepur, Gazipur
}

[Received: November 23, Accepted: December 30, 2013]

\begin{abstract}
A cross-sectional study was conducted to estimate the seroprevalence of Newcastle disease (ND) in backyard chickens at Gazipur district of Bangladesh. Individual serum sample was collected from clinically healthy and non-immunized backyard chickens in four randomly selected upazilla (Sreepur, Kapasia, Kaliakor and Gazipur sadar) under Gazipur district. A total of two hundred samples (50 from each upazila) were collected from October 2009 to February 2010. Haemagglutination Inhibition (HI) test was used to determine titer of antibodies against Newcastle disease virus. The mean $\log _{2} \mathrm{HI}$ titer to NDV in blood sera of the study population were found 5.54, 6.25, 4.38, 5.32 and seroprevalence were $42.53 \%, 45.99 \%, 31.91 \%$, and37.82\% in Sreepur, Kapasia, Kaliakor and Gazipur sadar upazilas respectively. The overall antibody titer and seroprevalence of Newcastle disease virus was recorded 5.37 and $39.56 \%$ respectively. Further detailed study focusing on Newcastle Disease (ND) virus strain identification and improved management packages to reduce the prevalence of Newcastle Disease (ND) are recommended.
\end{abstract}

Key words: Chickens, Newcastle Disease, Seroprevalence

\section{INTRODUCTION}

Bangladesh is agriculture based tropical country where over $80 \%$ of (about 150 million) people live in rural areas and are dependent on agriculture. Livestock is a major part of agriculture contributing $6.5 \%$ to national GDP on the basis of value added through their production of egg, milk, meat, hides and skins. The growth rate at $7.23 \%$ in GDP in 200405 for livestock was the highest of any sub-sector comparing with $0.15 \%$ for arable crops and $3.65 \%$ for fisheries ${ }^{[1]}$. Poultry is in the top position of the livestock sector. There are approximately 160 million chickens in the total poultry population of Bangladesh ${ }^{[2]}$ and backyard chickens constitute nearly $80 \%$ of the total chicken population ${ }^{[3]}$. Gazipur district is a major poultry belt in Bangladesh. The total poultry population in Gazipur is estimated to be around 4 million. This district stands out as the place of commercial poultry production but there is a substantial $(50 \%)$ backyard chicken population compared to commercial poultry population ${ }^{[4]}$. The backyard chicken production system is characterized by minimal human involvement, with birds scavenging in the backyard for food, and small investments beyond the cost of the foundation stock, a few handfuls of local grain, and possibly simple night shades, low production , high morbidity and high losses due to diseases and predation ${ }^{[5]}$. Among the highly prevailed infectious disease of backyard chickens, Newcastle disease is the foremost cause of mortalities in the backyard chickens ${ }^{[6,7,8]}$. Newcastle Disease (ND) is one of the most important infectious diseases in birds throughout the world. It is an endemic and sometimes epizootic disease in chickens and is caused by an avian Paramyxovirus type 1 (APMV 1), which is a member of the genus Avulavirus of the family Paramyxoviridae [9], which possess two surface proteins that are important to the identification and behavior of the virus . The first, hemagglutinin/neuraminidase (HN), is important in the attachment and release of the virus from the host cells, in addition to its serologic identification ${ }^{[10]}$. The other very important surface protein is the fusion (F) protein, which has a critical role in the pathogenesis of the disease ${ }^{[10]}$. Newcastle disease viruses occur in three pathotypes; lentogenic, mesogenic and velogenic reflecting increasing levels of virulence ${ }^{[11]}$. In chickens ND is characterized by lesions in the brain or gastrointestinal tract, morbidity rates near $100 \%$ and mortality rates as high as $90 \%$ in susceptible chickens. Neurological symptoms or severe depression are the most obvious clinical signs of ND, and some unvaccinated birds may be found dead with no detected sign of prior illness ${ }^{[12]}$. Newcastle disease virus (NDV) infections of poultry range from in apparent to rapid fatal depending upon the pathotype of virus involved ${ }^{[13]}$. Wild and domesticated birds sometimes harbor the Newcastle disease virus (NDV) while showing no detectable clinical signs of the disease ${ }^{[14]}$. In countries where poultry are kept exclusively in bird proof housing, the ability of the feral birds to invade affected flocks and transfer the disease will be minimal, whereas birds kept on open range are more likely to be infected with strains carried by feral birds $[15,16]$. Due to heavy load of commercial 
chickens and presence of feral birds close contact with backyard chickens resulting in transmission of infectious agents such as Newcastle disease virus but little is known about disease status of backyard chickens. The objectives of this study were to estimate the seroprevalence of Newcastle disease virus by hemagglutination inhibition $(\mathrm{HI})$ test of the backyard chickens.

Table: Antibody titer and Seroprevalence of NDV in backyard chickens at four upazilas in Gazipur district.

\section{MATERIALS AND METHODS}

\section{Study area and study design}

A cross-sectional study was conducted on backyard chickens sampled from four randomly selected upazilla (Sreeper, Kapasia, Kapliakor and Gazipur sadar) under Gazipur district.

\section{Sample size and sampling}

A total of 200 blood samples $(2 \mathrm{ml})$ were collected from the wing vein of birds (Unvaccinated, mature and apparently healthy chickens) belonging to four upazilla (50 from each) after giving identification number to all birds. From randomly sampled birds $2 \mathrm{ml}$ of blood were collected from the wing vein and laid nearly $45^{\circ}$ angle at room temperature for about 1hour to collect serum and subsequently stored at $-8^{\circ} \mathrm{C}$ until used. of $4 \mathrm{HAU}$ of antigen. Agglutination was assessed by tilting the pales. Only those wells in which the RBCs stream at the same rate as the control wells (containing $0.025 \mathrm{ml} \mathrm{RBCs}$ and $0.05 \mathrm{ml}$ PBS only) were considered to show inhibition.

\section{Statistical analysis}

The data were recorded and imported to Microsoft office excel worksheet 2007. The data were analyzed to calculate the prevalence of ND by using Microsoft office excel worksheet 2007.

\section{RESULTS}

Results of the investigation revealed that all the upazilas had chickens that were positive for antibodies to Newcastle disease virus (NDV). The mean antibody titer against NDV in backyard chickens sera were found 5.54, 6.25, 4.38, 5.32 and seroprevalence were $42.53 \%, 45.99 \%, 31.91 \%$ and $37.82 \%$ in Sreepur, Kapasia,Kaliakor and Gazipur sadar upazila of Gazipur district respectively (Table). The overall antibody titer against Newcastle disease virus was recorded 5.37 and seroprevalence was $39.56 \%$. However, a relatively higher seroprevalence was observed at Kapasia (45.99\%) and the lowest at Kaliakor (31.91\%). It might be due to lack of vaccination and improper biosecurity practice in Kapasia. In kaliakor the seroprevalence was lower due to improved management practice.

\begin{tabular}{|c|c|c|c|c|c|c|c|c|}
\hline \multirow[b]{3}{*}{$\begin{array}{l}\text { Study } \\
\text { areas } \\
\text { (Upazila) }\end{array}$} & \multicolumn{8}{|c|}{ Study chickens } \\
\hline & \multicolumn{3}{|c|}{ Male } & \multicolumn{2}{|c|}{ Female } & \multicolumn{3}{|c|}{ Total } \\
\hline & No. & $\begin{array}{l}\text { Seroprevalenc } \\
(\%)\end{array}$ & Titre & No. & $\begin{array}{l}\text { Seroprevalence } \\
(\%)\end{array}$ & Titre & $\begin{array}{l}\text { Seropre } \\
\text { valence }\end{array}$ & Titre \\
\hline Sreepur & 32 & $40.62 \%$ & 5.03 & 18 & $44.44 \%$ & 6.05 & $42.53 \%$ & 5.54 \\
\hline Kapasia & 24 & $45.83 \%$ & 5.89 & 26 & $46.15 \%$ & 6.61 & $45.99 \%$ & 6.25 \\
\hline Kaliakor & 19 & $31.58 \%$ & 4.50 & 31 & $32.25 \%$ & 4.26 & $31.91 \%$ & 4.38 \\
\hline $\begin{array}{l}\text { Gazipur } \\
\text { sadar }\end{array}$ & 22 & 36.36 & 5.28 & 28 & $39.28 \%$ & 5.36 & $37.82 \%$ & 5.32 \\
\hline Total & 97 & $38.597 \%$ & 5.175 & 103 & $40.53 \%$ & 5.57 & $39.56 \%$ & 5.37 \\
\hline
\end{tabular}

\section{Sample analysis}

The hemagglutination inhibition (HI) test was performed to detect antibodies against the ND virus. The HI test was done following procedures outlined by the Office International des Epizooties [17, 18]. Briefly, the test was carried out by running twofold dilutions of equal volumes $(0.025 \mathrm{ml})$ of phosphate buffered saline (PBS) and test serum $(0.025 \mathrm{ml}$ of $1 \%$ in V-bottomed micro titer plates. Four hemagglutinating units (HAU) of virus/antigen were added to each well and the plates were left at room temperature for a minimum of 30 minutes. Finally, $0.025 \mathrm{ml}$ of $1 \%$ (volume/volume) chicken red blood cells $\left(\mathrm{RBC}_{\mathrm{s}}\right)$ were added to each well and after gentle mixing, allowed to settle for about 40 minutes at room temperature. The HI titer was read from the highest dilution of serum causing complete inhibition

\section{DISCUSSION}

The present study showed the occurrence of a relatively higher seroprevalence of ND virus antibodies in local chickens in all four selected upazilas. The overall higher seroprevalence of ND virus antibodies in local chickens was attributed to a number of factors. The attributed factors may be the management system in traditional production may serve as a stress factor and favor infection. Poor sanitary conditions, continuous exposure of chickens to range conditions and wild birds, nutritional deficiencies, the absence of vaccination in traditionally managed chickens, and contact of chickens of one village with those in other villages may facilitate the spread of ND. This is 
in concurrence with the reports by ${ }^{[19]}$. The ease of contact of chickens from different areas at local open-air markets, which are then taken back to various localities, can undoubtedly facilitate the rapid spread and persistence of ND among local chickens ${ }^{[12]}$ has reported a $72 \%$ seroprevalence rate of antibodies to ND virus in traditionally managed, non-vaccinated village chickens in Nigeria. This study showed ND to be one of the major infectious diseases that reduces the number and productivity of traditionally managed chickens in the study area. The data clearly indicate that local chickens kept under free- range traditional management systems- in which chickens literally scavenge their own feed and water were exposed to ND virus.

Identification of distance to neighboring poultry farms as a risk factor in our study in consistent with ${ }^{[13]}$ who listed airborne spread as one mechanism for the spread of NDV .This mechanism was considered for significant factor in the 1970-1971 ND outbreaks in England ${ }^{[20]}$. The result of an serological study was conducted by ${ }^{[21]}$ showed that the ND, responsible for $44.3 \%$ of all mortality recorded during the 12 month period (from May 1999 to June 2000) in village poultry farming in Madagascar and maximum incidence of the disease was $71 \%$ and seroprevalence often reached $100 \%$ after the outbreak had ended .The infection was brought to the villages either by newly introduced hens or recovered birds. All forms of Newcastle disease (epidemic, endemic and asymptomatic) were observed. These way farmers reacted and contributed to the spread of the virus within the village and to neighboring locations. In our study, the movement of people, vehicles and fomites between industrial neighboring poultry farm and villages is another risk factor for transmission of NDV to backyard chickens and vice versa ${ }^{[13]}$. Age of the sampled chickens was another risk factor in our study, because the prevalence of seropositive samples and the average backyard chickens antiNDV antibody titer increased with the increasing chicken age ${ }^{[22]}$. Epidemiological study of Newcastle disease in backyard poultry and wild bird populations in Switzerland suggests that buying eggs and poultry abroad and exchanging poultry within the country were factors, more important than wild birds, to explain the higher NDV seropositivity in pure-bred poultry flock ${ }^{[23]}$. In a cross-sectional survey of Australian chicken farms to identify risk factors associated with seropositivity to ND virus, the overall prevalence of NDV seropositive farm was $39.8 \%{ }^{[22]}$. In another serological and virological survey for evidence of infection with NDV in Australian chicken farms, antibody evidence of ND virus infection was found on 300 of the 553 surveyed farms throughout all 11 geographic regions of the survey. Antibody titers were also highest in the regions where serologically positive flocks were most prevalent and concluded that the antibodies to ND virus are highly prevalent in the Australian chicken flock but all identified strains were avirulent in nature ${ }^{[24]}$. Poultry diseases such as ND were shown to be the most important constraints on local chicken production. ND is the most important cause of loss in village dwelling as well as commercially raised chickens. The disease occurs almost any time of year and velogenic strains of ND virus are widely distributed throughout the country ${ }^{[25]}$. It is therefore vitally important that further detailed studies focus on ND virus strain identification is required so that preventive and control programs can be formulated.

\section{CONCLUSION}

In the study it was demonstrated that the risk of backyard chicken flocks being seropositive for Newcastle disease virus increased with increasing age of the flock, increasing proximately to the nearest neighbor poultry farm and presence of wild and migratory birds in the vicinity of the backyard chicken flocks. High prevalence of ND was found in Kapasia upazilla, so proper biosecurity and control measures should be taken in kapasia upazilla and regular vaccination should be performed in this area. Besides, commercial poultry become facing high risk due to spread of Newcastle disease virus by backyard poultry. So proper potential measures for the control of ND should be taken to save the backyard chickens.

\section{REFERENCES}

1. Bangladesh economic review (2006). Ministry of finance, Government of the People's Republic of Bangladesh, Dhaka, Bangladesh.

2. Ahammad K (2005). Poultry Business Guide. Poultry khamarbichitra, Dhaka, Bangladesh.

3. Directorate of Livestock Services (DLS) (1998). Expansions and Activities. Department of Livestock Services, Dhaka, Bangladesh.

4. Bangladesh Bureau of Statistics (BBS) (2006). Agriculture Sample Survey of Bangladesh2005. Planning Division, Ministry of Planning, Government of the People's Republic of Bangladesh.

5. Kitalyi AJ (1998). Village chicken production systems in Africa: Household food security and gender issues. FAO Animal Production and Health paper. 142 Rome. pp. 81.

6. Melewas JN (1989). The contribution of poultry industry to the national economy. In: Proceedings of the $7^{\text {th }}$ Tanzania Veterinary Association Scientific Conference, Arusha, Tanzania. pp. 13-35.

7. Minga UM, Katule AM, Maeda T, Musasa J (1989). Potential of the traditional chicken Industry in Tanzania. In: Proceedings of the $7^{\text {th }}$ Tanzania Veterinary Association Scientific Conference, Arusha, Tanzania. pp. 207-215. 
8. Awan MA, Otte MJ, James AD (1994). The epidemiology of Newcastle disease in rural poultry: A review. Avi. Path. 23:405-423.

9. Mayo MA (2002). Virus Taxonomy. Arch. Virol. 147:1071-1076.

10. Beard CW, Hanson HP, Hofstad MS, Bames HJ, Calnek BW, Reid BM, Yoder HW (1984). Newcastle Disease. In Diseases of Poultry. $8^{\text {th }}$ ed. Iowa State University Press, USA. pp. 452-470.

11. Alexander DJ (1997). Newcastle disease and other Paramyxovirus infections. In: Calnek BW, Barnes HJ, Beard CW, McDougal LR, Saif YM, eds. Diseases of poultry. $10^{\text {th }}$ ed. Ames, IA: Iowa State University Press.

12. Eskoli CD (1984). Prevalence of disease virus antibodies in local and exotic chickens under different management systems in Nigeria. Bull. Anim. Health. Prod. Africa 32:253-257.

13. Alexander DJ (2003). Newcastle disease, other avian Paramyxoviruses and pneumovirus infections: Newcastle disease. In Diseases of Poultry, Saif YM, Iowa State University Press, USA. pp. 64-87.

14. Lancaster JE (1964). Newcastle disease control by vaccination: a review article. Vet. Bullet. 34:57-76.

15. Wobeser G, Leighton FA, Norman R, Myers DJ, Onderka D, Pybus MJ (1993). Newcastle disease in wild water birds in Western Canada. Can. Vet. J. 34:353-359.

16. Onapa OM, Christensen H, Mukiibi GM, Bisgaard M (2006). A preliminary study of the role of ducks in the transmission of Newcastle disease virus to in contact rural free-range chickens. Trop. Anim. Health. Prod. 38:285289.

17. Office International Des Epizooties (OIE) (2000). Manual of Standards for Diagnostic Tests and Vaccines. $4^{\text {th }}$ ed. Paris, France.
18. Beard CW (1989). Serologic procedures. In: Purchase HG et al., eds. A Laboratory Manual for the isolation and Identification of Avian Pathogens. $3^{\text {rd }}$ ed. Kennet Square, PA: American Association of Avian Pathologists. pp. 192-200.

19. Dessie T, Ogle B (1996). .A Survey of Village poultry Production in the Central Highlands of Ethiopia. Part 1. (Master's thesis). Swedish University of Agricultural Sciences, Uppsala, Sweden.

20. Hugh-Jones M, Allan WH, Dark FA, Harper GJ (1973). The evidence for the airborne spread of Newcastle disease. J. Hyg. Camb. 71:325-339.

21. Maminiaina OF, Koko M, Ravaomanana J, Rakotonindrina SJ (2007). Epidemiology of Newcastle disease in village poultry farming in Madagascar. Rev. Sci. Technol. 26:691-700.

22. East I, Kite V, Daniels P, Garner G (2006). A cross-sectional survey of Autralian chicken farms to identify risk factors associated with seropositivity to Newcastle disease virus. Prev. Vet. Med. 77:199-214.

23. Gohm D, Schelling E, Audige L, Thur B (1999). Newcastle disease seroepidemiologic study of a highly contagious epizootic in poultry and in wild birds in Switzerland. Schweiz. Arch. Tierheilkd. 141(12):549-58.

24. Kite VG, Boyle DB, Heine HG, Pritchard I, Garner MG, East IJ (2007). A serological and virological survey for evidence of infection with Newcastle disease virus in Australian chicken farms. Aust. Vet. J. 85: 236-242.

25. Sonaiya EB (1990). The context and prospects for development of smallholder rural poultry production in Africa. In: CTA-Seminar proceedings on smallholder rural poultry production, Thessaloniki, Greece. pp. 35-52. 